\title{
SISTEM SECURITY WEBCAM DENGAN MENGGUNAKAN MICROSOFT VISUAL BASIC (6.0)
}

\author{
Julfikar Ali andre \\ Jurusan Teknik Informatika, STMIK Amik Riau \\ Jl.Purwodadi Indah KM.10, Panam- Pekanbaru \\ E-Mail: andre.yosefa06@ymail.com
}

\begin{abstract}
ABSTRAK
Webcam (Web Camera) adalah sebutan bagi kamera real-time (bermakna keadaan pada saat ini juga) yang gambarnya bisa diakses atau dilihat melalui World Wide Web, program instant messaging, atau aplikasi video call Selama ini, aplikasi webcam hanya digunakan untuk merekam dan menampilkan objek, tetapi belum pernah digunakan untuk aplikasi lain seperti aplikasi keamanan yang digunakan untuk mendeteksi gerakan objek. Webcam tidak dapat memberikan informasi tentang gerak suatu objek, objek pasif atau aktif. Karena itu, penelitian untuk meningkatkan sistem untuk dapat mendeteksi gerakan dari gambar yang tertangkap dari webcam ini perlu dilakukan. Sistem deteksi gerak dari sebuah objek bekerja jika objek tertangkap memiliki posisi berubah, dan secara otomatis akan mengaktifkan alarm. Metode pengolahan citra yang digunakan dalam deteksi gerakan metode deteksi tepi, sedangkan untuk proses deteksi gerak, proses perbandingan posisi pixel yang digunakan.
\end{abstract}

Kata kunci : sistem security webcam, deteksi gerak, pengolahan citra.

\begin{abstract}
Webcam (Web Camera) is the designation for the real-time camera (meaning the circumstances of today) in which the pictures can be accessed or viewed via the World Wide Web, instant messaging program, or a video call application. During this time, the webcam application is only used to record and display objects, but has never been used for other applications such as security applications that are used to detect object movemen. Webcam can not provide information about the motion of an object, the object is passive or active. Therefore, research to improve the system to be able to detect the movement of the image captured from webcam needs to be done. Motion detection system of an object works if the object captured has changed position, and will automatically activate the alarm. Image processing method used in motion detection edge detection method, whereas for motion detection process, the process of comparison of the position of pixels used.
\end{abstract}

Key Word : sistem security webcam, motion detection, pixels used.

\section{PENDAHULUAN}

Perkembangan teknologi kamera yang semakin pesat sekarang ini ditandai dengan munculnya berbagai macam kamera digital seperti StreetCamera yang memperlihatkan pemandangan jalan, MetroCamera yang memperlihatkan pemandangan panorama kota dan pedesaan, TraffiCamera yang digunakan untuk memonitor keadaan jalan raya, WeatherCamera yang digunakan untuk melihat keadaan cuaca, bahkan keadaan gunung berapi bisa dipantau dengan VolcanoCamera, selain dari beberapa hal tersebut webcam (web camera) juga dapat merekam atau menangkap gambar yang bergerak dalam bentuk video.

Dengan kemajuan teknologi kamera saat ini pengamatan suatu objek menjadi lebih praktis. Untuk mengamati suatu benda tidak perlu dilakukan pengamatan secara langsung dan terus-menerus pada suatu objek, namun cukup meletakkan suatu kamera yang mengarah pada objek yang diinginkan lalu mengamatinya dari layar monitor dengan mengamati citra yang terekam kamera maka dapat diketahui kondisi dari objek tersebut.

Masalah timbul karena selama ini kamera hanya dapat menangkap suatu objek tetapi tidak 
dapat memberikan informasi tentang gerakan dari objek tersebut. Penentuan gerakan objek tersebut biasanya dilakukan dengan mengamati citra yang terekam oleh kamera. Hal ini menjadi tidak efektif bila terlalu banyak citra yang akan diamati dan hal ini memungkinkan terjadinya kesalahan pengamatan hal inilah yang mendasari pembuatan program pendeteksi gerakan suatu objek. Sistem ini akan mendeteksi gerakan yang tertangkap oleh kamera dan akan mengaktifkan alarm. Dengan demikian gerakan yang tidak dikehendaki pada suatu ruangan atau objek dapat terdeteksi dengan baik.

Pembuatan sistem keamanan ini dibuat dengan memanfaatkan kamera yang sudah terdapat pada laptop, yaitu webcam sebagai pengambil gambar suatu objek ketika ada suatu objek yang terdeteksi oleh kamera. Salah satu kelemahan dari webcam adalah kurang mampu mengambil objek pada ruang gelap yang menyebabkan objek yang ditangkap menjadi kurang jelas.

Metode deteksi gerak adalah proses perbandingan antara gambar (capture) pertama dengan kedua sehingga pada saat suatu objek terdeteksi kamera maka alarm akan berbunyi. Objek gambar yang akan diambil harus dalam keadaan diam. Untuk mempermudah proses pengolahan gambarnya maka kapasitas atau ukuran pixcels pada citra hanya menggunakan satu jenis ukuran pixcels, di samping itu juga memandang kekuatan dari webcam itu sendiri mengenai jarak maksimal pengambilan gambarnya di mana semakin jauh jarak kamera terhadap objek maka objek akan terlihat semakin kecil dan menjadi kurang jelas.

\section{Perumusan Masalah}

Berdasarkan latar belakang masalah tersebut diatas, dapat dirumuskan permasalahan sebagai berikut:
1. Bagaimana memanfaatkan Webcam yang sudah tesedia pada laptop sebagai sistem keamanan?

2. Bagaimana membuat software menggunakan teknik pengolahan citra digital untuk sistem keamanan?

3. Bagaimana cara kerja security webcam untuk mengcapture objek yang bergerak?

4. Bagaimana membuat software deteksi gerak dengan menggunakan Microsoft Visual Basic (VB 6.0)?

\section{Batasan Masalah}

Agar pembahasan dalam tugas akhir ini tidak meluas, maka bahasan pada penulisan tugas akhir ini hanya membahas mengenai sistem security wabcam dengan menggunakan webcam sebagai alat bantunya. Adapun batasan yang digunakan sebagai acuan dalam perancangan sistem keamanan ini adalah:

1. Sistem keamanan yang dirancang dipergunakan untuk ruangan tertutup dengan daerah yang tidak terlalu luas dan mempunyai penerangan yang tetap.

2. Capture device yang digunakan adalah webcam yang sudah terfasilitasi dilaptop.

3. Jarak objek terhadap kamera.

\section{Manfaat dan Tujuan Penelitian}

Manfaat yang dapat diperoleh dari perancangan sistem security webcam bagi penggunanya adalah:

1. Bagi pihak yang terkait atau pengguna sistem Manfaat yang didapat bagian security adalah pemberitahuan informasi akurat yang dapat dilakukan dengan cepat, tepat, dan efisien, dapat mengurangi kesalahan dalam pendeteksian suatu objek, serta dapat memberikan laporan yang baik kepada pemilik atau pengguna sistem.

\section{Sejarah Perkembangan Webcam (web camera)}

Dimulai pada tahun 1991 kamera pertama yang disebut dengan CoffeeCam digunakan 
untuk memantau ruangan kopi Trojan di departemen ilmu komputer dari Universitas Cambridge. CoffeCam adalah webcam tertua dan sebagai teknologi yang kemudian menjadi acuan untuk pengembangan webcam generasi berikutnya.

Pada awalnya, bentuk webcam terbatas pada bentuk-bentuk standar yang hanya terdiri dari lensa dan papan sirkuit serta casing yang biasa. Namun seiring dengan perkembangan teknologi, bentuk webcam sudah semakin bervariasi dengan fitur-fitur yang semakin canggih. Salah satu bentuk webcam yang unik adalah bentuk boneka yang lucu, webcam ini dapat disalah artikan hanya sebagai boneka dan bukan webcam. Sebuah penemuan oleh Microsoft pada tahun 2004 menggambarkan kemajuan perkembangan teknologi webcam yaitu $i 2 i$ (dual camera) adalah sebuah sistem duakamera yang dengan sangat hati-hati mengikuti pergerakan individu. Kamera ini menggunakan perhitungan algoritma yang secara spesial dikembangkan untuk memfungsikan apa yang setiap kamera lihat untuk membuat gambar yang akurat. Kamera ini juga dapat menampilkan tampilan tiga dimensi (3D) yang melayang. Sistem i2i dapat juga menghasilkan gambar background yang realistis sehingga pengguna dapat berpura-pura berada di tempat lain. Kemampuan sistem i2 diantaranya yaitu kemampuan tracking (disebut smart framing) dan juga kemampuan smart focusing dapat menambah pengalaman berkonferensi bagi pengguna.

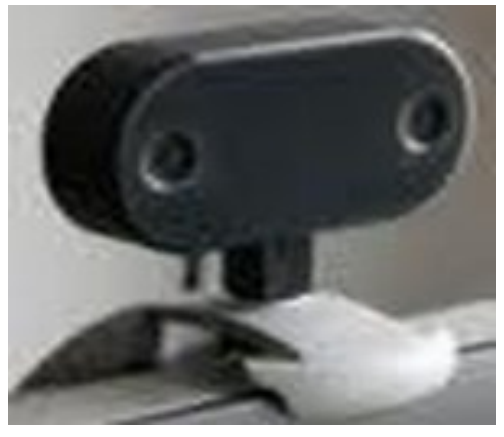

Gambar 2.1: Webcamera i2i

Teknologi webcam pada awalnya mendapat dukungan komersial dari industri pornografi. Industri ini membutuhkan gambargambar 'live' dan meminta pembuatan software yang mampu melakukannya tanpa web browser plugins. Hal ini melahirkan teknologi live streaming webcam yang masih tetap ada hingga sekarang. Sekarang ini webcam yang ada di pasaran pada umumnya terbagi ke dalam dua tipe: webcam permanen (fixed) dan revolving webcam. Pada webcam permanen terdapat pengapit untuk mengapit lensa standar di posisi yang di inginkan untuk menangkap gambar pengguna. Sedangkan pada revolving webcam terdapat landasan dan lensa standar dipasang di landasan tersebut sehingga dapat disesuaikan ke sudut pandang yang terbaik untuk menangkap gambar pengguna. Penggunaan webcam mencakup video conferencing, internet dating, video messaging, home monitoring, images sharing, video interview, video phone-call, dan banyak lagi jenis kamera lainnya. Kamera untuk video conference biasanya berbentuk kamera kecil yang terhubung langsung dengan komputer. Kamera analog, kamera ini terhubung dengan video capture card dan tersambung dengan internet (baik langsung maupun tidak langsung). Saat ini kamera untuk video conference sudah makin maju, sudah ada webcam yang di dalamnya terdapat microphone maupun noise cancellation untuk memfokuskan audio ke speaker yang terletak di depan kamera sehingga noise yang ada tidak mengganggu jalannya konferensi.

\section{Pengertian Webcam}

Webcam (singkatan dari web camera) adalah sebutan bagi kamera real-time (bermakna keadaan pada saat ini juga) yang gambarnya bisa diakses atau dilihat melalui World Wide Web, program instant messaging, atau aplikasi video call $^{l}$.

sehingga kata web kadang-kadang diganti dengan kata lain yang mendeskripsikan pemandangan yang ditampilkan di kamera, 
misalnya StreetCam yang memperlihatkan pemandangan jalan ada juga Metrocam yang memperlihatkan pemandangan panorama kota dan pedesaan, TraffiCam yang digunakan untuk memonitor keadaan jalan raya, cuaca dengan Weather Cam, bahkan keadaan gunung berapi dengan VolcanoCam.

Webcam adalah sebuah kamera video digital kecil yang dihubungkan ke komputer melalui port USB ataupun port COM dan hingga sekarang webcam sudah lebih maju dan tertanam lansung dilaptop tanpa menggunakan port USB.

\subsubsection{Tipe-Tipe Webcam}

Slim1320 (True 1.3 Mega Pixels High Performance Webcam), Slim 2020AF (Mega Pixel Webcam Auto Focus), Eye 312 (Simplify Instant Video and Chat), Eye 110 (Instant Video Messenger Webcam) serta i-Look 1321 (Advance 1.3 Mega Pixel Camera), dan lain-lain. Sekarang hampir semua kamera digital dan HP bisa dijadikan sebagai kamera web (webcam).

\section{Cara Kerja Webcam}

Sebuah web camera yang sederhana terdiri dari sebuah lensa standar, dipasang di sebuah papan sirkuit untuk menangkap sinyal gambar; casing (cover), termasuk casing depan dan casing samping untuk menutupi lensa standar dan memiliki sebuah lubang lensa di casing depan yang berguna untuk memasukkan gambar; kabel support, yang dibuat dari bahan yang fleksibel, salah satu ujungnya dihubungkan dengan papan sirkuit dan ujung satu lagi memiliki connector, kabel ini dikontrol untuk menyesuaikan ketinggian, arah dan sudut pandang web camera. Sebuah web camera biasanya dilengkapi dengan software, software ini mengambil gambargambar dari kamera digital secara terus menerus ataupun dalam interval waktu tertentu dan menyiarkannya melalui koneksi internet. Ada beberapa metode penyiaran, metode yang paling umum adalah software mengubah gambar ke dalam bentuk file JPEG dan menguploadnya ke web server menggunakan File Transfer Protocol (FTP).

Frame rate mengindikasikan jumlah gambar sebuah software dapat ambil dan transfer dalam satu detik. Untuk streaming video, dibutuhkan minimal 15 frame per second (fps) atau idealnya $30 \mathrm{fps}$. Untuk mendapatkan frame rate yang tinggi, dibutuhkan koneksi internet yang tinggi kecepatannya. Sebuah web camera tidak harus selalu terhubung dengan komputer, ada web camera yang memiliki software webcam dan web server bulit-in, sehingga yang diperlukan hanyalah koneksi internet. Web camera seperti ini dinamakan "network camera". Kita juga bisa menghindari penggunaan kabel dengan menggunakan hubungan radio, koneksi Ethernet ataupun WiFi.

\section{Security (Keamanan)}

Keamanan adalah keadaan bebas dari bahaya. Istilah ini bisa digunakan dengan hubungan kepada kejahatan, segala bentuk kecelakaan, dan lain-lain. Keamanan merupakan topik yang luas termasuk keamananan nasional terhadap serangan teroris, keamanan komputer terhadap hacker, kemanan rumah terhadap maling dan penyelusup lainnya, keamanan finansial terhadap kehancuran ekonomi dan banyak situasi berhubungan lainnya.

\section{Security Webcam}

Sekitar pergantian abad ke-21, produsen hardware komputer mulai membangun Webcam langsung ke laptop layar dan desktop, sehingga menghilangkan kebutuhan untuk menggunakan USB eksternal atau Firewire kamera. Secara bertahap Webcam datang untuk menjadi lebih banyak digunakan untuk telekomunikasi, atau video telephone, antara dua orang atau lebih.

Dengan seiringnya kemajuan teknologi, kini webcam tidak hanya sebagai alat pengambil gambar, video dan alat komunikasi dua arah $\frac{\text { tetapi webcam juga dapat digunakan sebagai }}{\text { Penulis Pertama: Julfikar Ali Andre }}$ 
kamera keamanan dimana webcam berkerja dengan cara mendeteksi objek yang bergerak dan memberikan informasi kepada user atau admin dengan alert alarm dan lain sebagainya. Objek yang terdeteksi atau terekam dapat disimpan ke komputer, e-mail atau upload ke Internet. Dengan adanya security wabcam memungkinkan pemiliknya untuk memberikan gambaran yang jelas kepada polisi jika terjadi suatu tindakan kriminal. Pada saat ini hampir semua aspek menggunakan sistem security webcam karena dengan adanya sistem ini dapat menekan tindakkan kriminal serta mempermuda pihak yang berwajib untuk mengidentifikasi para pelaku kejahatan dengan cepat dan akurat.

\section{Pengertian Citra Digital}

Citra digital merupakan fungsi intensitas cahaya $\mathrm{f}(\mathrm{x}, \mathrm{y})$ pada bidang 2D, dimana harga $\mathrm{x}$ dan y merupakan koordinat spasial dan nilai fungsi tersebut pada setiap titik $(\mathrm{x}, \mathrm{y})$ merupakan tingkat kecemerlangan citra pada titik tersebut. Citra dapat berbentuk foto hitam putih atau berwarna, sinyal-sinyal video seperti gambar pada monitor televisi, atau bersifat digital yang dapat langsung disimpan pada suatu pita magnetik. Menurut presisi yang digunakan untuk menyatakan titik-titik koordinat pada ranah waktu atau bidang dan untuk menyatakan nilai keabuan atau warna suatu citra, maka secara teoritis citra dapat dikelompokkan menjadi empat kelas citra, yaitu cara continue-continue, continue-diskret, diskret-continue, dan diskretdiskret; dengan label pertama menyatakan presisi dari titik-titik koordinat pada bidang citra sedangkan label kedua menyatakan presisi nilai keabuan atau warna. Continue dinyatakan dengan presisi takhingga, sedangkan diskret dinyatakan dengan presisi angka berhingga. Pengubahan citra yang bersifat continue menjadi citra yang bersifat diskret memerlukan pembuatan kisi-kisi arah vertikal dan horisontal, sehingga diperoleh citra dalam bentuk larik dua dimensi. Proses tersebut dikenal sebagai proses pencuplikan (sampling). Setiap elemen larik tersebut dikenal sebagai elemen gambar atau pixcel.

\section{Pengolahan Citra Digital}

Pengolahan Citra merupakan proses pengolahan dan analisis citra yang banyak melibatkan persepsi visual. Proses ini mempunyai ciri data masukan dan informasi keluaran yang berbentuk citra. Proses pengolahan citra dalam bentuk digital secara umum mempertimbangkan masalah peningkatan mutu citra atau perbaikan citra. Istilah pengolahan citra digital secara umum didefinisikan sebagai pemrosesan citra dua dimensi dengan komputer. Dalam definisi yang lebih luas, pengolahan citra digital juga mencakup semua data dua dimensi. Citra digital adalah barisan bilangan nyata maupun kompleks yang diwakili oleh bit-bit tertentu. Proses pengolahan citra digital dapat dilihat pada Gambar 2.1.

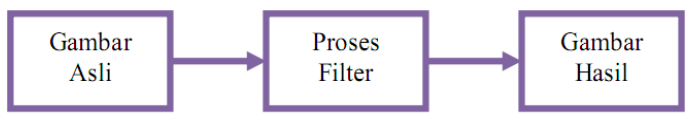

Gambar 2.1: Blok Diagram Pengolahan Citra Digital

Sumber gambar :http: / / www . google .co . id /\# $\mathrm{hl}=\mathrm{id} \&$ source $=$ pengolahan + citra

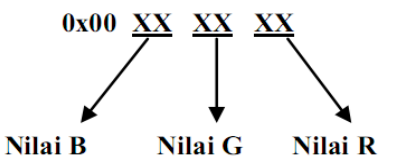

\section{Gambar 2.2: Nilai warna RGB dalam hexadesimal}

Terlihat bahwa setiap warna mempunyai range nilai 00 (angka desimalnya adalah 0 ) dan ff (angka desimalnya adalah 255), atau mempunyai nilai derajat keabuan $256=2^{8}$.Dengan demikian range warna yang digunakan adalah $\left(2^{8}\right)\left(2^{8}\right)\left(2^{8}\right)$ $=2^{24}$ (atau yang dikenal dengan istilah True 
Colour pada Windows). Nilai warna yang digunakan di atas merupakan gambungan warna cahaya merah, hijau dan biru seperti yang terlihat pada gambar 2.3. Sehingga untuk menentukan nilai dari suatu warna yang bukan warna dasar digunakan gabungan skala kecerahan dari setiap warnanya.

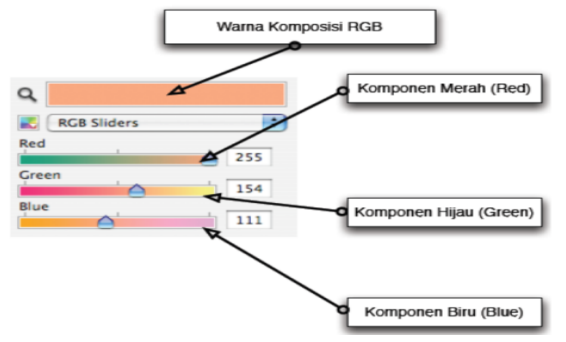

Gambar 2.3: Komposisi warna RGB

Prinsip dasar dari pengolahan citra adalah pengolahan warna RGB pada posisi tertentu. Dalam pengolahan citra warna dipresentasikan dengan nilai hexadesimal dari 0x00000000 sampai 0x00ffffff. Warna hitam adalah 0x00000000 dan warna putih adalah 0x00ffffff. Definisi nilai warna di atas seperti gambar 2.4. Variabel 0x00 menyatakan angka dibelakangnya adalah hexadesimal.

Dari definisi diatas untuk menyajikan warna tertentu dapat dengan mudah dilakukan, yaitu dengan mencampurkan ketiga warna dasar RGB, table 2.1.

Tabel 2.1: Contoh warna dalam hexadesimal

\begin{tabular}{|l|l|}
\hline Nillai & Warna \\
\hline Ox00000000 & Hitam \\
\hline Ox000000FF & Merah \\
\hline Ox0000FF00 & Hijau \\
\hline Ox00FF0000 & Biru \\
\hline Ox0000FFFF & Kuning \\
\hline Ox00FF00FF & Magenta \\
\hline Ox00FFFF00 & Cyan \\
\hline Ox00FFFFFF & Putih \\
\hline
\end{tabular}

\begin{tabular}{|l|l|}
\hline Nilai & Warna \\
\hline Ox0000AAFF & Orange \\
\hline Ox008888888 & Abu-abu \\
\hline Ox00FF00AA & Ungu \\
\hline Ox00AAFF00 & Hijau Muda \\
\hline Ox00AA00FF & Merah Muda \\
\hline Ox00AAFFFF & Kuning Muda \\
\hline Ox000088AA & Coklat \\
\hline Ox00AA00088 & Ungu \\
\hline
\end{tabular}

\section{Pixcel Dan Resolusi Citra}

Pixcel merupakan satuan komponen terkecil dari gambar yang menentukan ukuran DOI : https://doi.org/10.36341/rabit.vli2.23 dari suatu gambar. Resolusi citra menyatakan ukuran bit dari suatu citra dalam satuan pixcel. Untuk citra biner, pixcel gambar yang kecerahannya dibawah tingkat tertentu diwakili oleh "0" sedangkan diatasnya diwakili oleh "1" dengan demikian semua citra didalam memory komputer dapat diwakili oleh logika "1" dan " 0 ".

\section{Deteksi Gerakan (Motion Detection)}

Motion detection merupakan penelitian yang penting dalam keilmuan computer vision. Banyak metode motion detection yang telah ditemukan, satu diantaranya adalah dengan menghitung perbedaan nilai-nilai intensitas pada suatu piksel dari dua frame gambar yang diambil secara berturut-turut yang kemudian dilakukan proses thresholding untuk menentukan adanya perubahan objek atau tidak. Sekalipun metode ini sangat sederhana dalam proses implementasinya, tapi metode ini merupakan metode dasar dari proses motion detection. Hanya saja metode ini kurang efektif untuk menentukan pergerakan objek secara keseluruhan, terutama bagian dalam dari objek yang bergerak, akan tetapi secara umun metode ini sudah mampu mengidentifikasi adanya perubahan objek. Pengurangan nilai-nilai intensitas setiap piksel yang ada pada background terhadap suatu image baru merupakan metode yang paling popular untuk proses motion detection.

Langkah-langkah dari motion detection secara umum adalah :

1. Memasukkan gambar pertama sebagai beckground.

2. Memasukkan gambar kedua sebagai gambar yang ada objeknya.

3. Gambar pada langkah ke satu dan ke dua lakukan scanline, fungsinya adalah untuk menemukan apakah ada perubahan objek atau tidak ada perubahan. Scanline dilakukan dari kiri atas gambar sampai dengan kanan bawah gambar. 
4. Lakukan perbandingan antara gambar background dengan gambar satunya lagi, hal ini dilakukan supaya bisa mengetahui adanya perubahan atau adanya perbedaan antara gambar kesatu dan gambar kedua. Pada langkah ini biasanya ada proses tresholding dan deteksi pinggiran jika diperlukan. Ini juga disebut proses motion detection.

5. Setelah melakukan proses diatas maka akan dihasilkan citra hasil motion detection.

Deteksi gerakan (motion detection) secara sederhana dapat dilakukan dengan mencari beda antara 2 buah citra yang berurutan pada hasil pencitraan menggunakan kamera video digital. Operator yang dapat digunakan adalah AND NOT. Dengan menggunakan operator AND NOT previous image dibandingkan dengan actual image. Persamaan yang digunakan dapat dilihat pada Persamaan berikut:

$$
\begin{aligned}
\mathrm{z}=\mathrm{x} & \text { AND NOT } \mathrm{y} \\
\text { Ket }: & \mathrm{z}=\text { output } \\
\mathrm{x} & =\text { previous image } \\
\mathrm{y} & =\text { actual image }
\end{aligned}
$$

Tabel 2.2: Tabel Kebenaran AND NOT

\begin{tabular}{|c|c|c|}
\hline \multicolumn{2}{|c|}{ Input } & Output \\
\hline $\mathbf{x}$ & $\mathbf{y}$ & $\mathbf{z}$ \\
\hline 0 & 0 & 0 \\
\hline 0 & 1 & 0 \\
\hline 1 & 0 & 1 \\
\hline 1 & 1 & 0 \\
\hline
\end{tabular}

Gerakan terdeteksi jika fraksi jumlah pixcel yang bernilai 1 lebih dari atau sama dengan batas ambang, atau bisa dituliskan seperti berikut:

$$
\left[\frac{\text { JumlahPiksel }}{\text { JumlahTotalPiksel }}\right] \geq \text { Batas.Ambang }
$$

dengan:

JumlahPixcel $=$ Jumlah pixcel yang bernilai 1

JumlahTotalPixcel $=$ Jumlah pixcel keseluruhan dalam frame

$$
\text { BatasAmbang = Ambang yang telah }
$$
ditentukan

\section{Metode Motion Detection}

Deteksi gerakan yang digunakan di aplikasi kamera pengawas pendeteksi gerakan ini adalah pemrosesan citra spatial domain dengan point processing. Metode ini bekerja dengan cara sebagai berikut :

1. Penetapan sebuah citra referensi

Sebuah citra yang diambil oleh kamera pada saat situasi lingkungan yang stabil ditetapkan sebagai citra referensi. Citra ini kemudian disimpan sebagai acuan dalam membandingkan citra.

2. Pengambilan citra secara periodik

Setiap jangka waktu tertentu, sebuah citra diambil oleh kamera. Citra ini kemudian disimpan untuk perhitungan selanjutnya.

3. Pendeteksian gerak

Citra yang diambil secara periodik tadi dibandingkan dengan referensi dengan cara membandingkan setiap pixcel yang berada di lokasi yang sama. Perhitungan perbandingan dilakukan dengan cara mengambil nilai absolute dari hasil pengurangan nilai RGB dari 2 pixcel yang berbeda dilokasi yang sama. Jika nilai dari perhitungan tersebut melewati suatu batas nilai tertentu maka pixcel tersebut dinyatakan sebagai pixcel yang terdeteksi gerakan.

$$
\mathrm{f}(\mathrm{x}, \mathrm{y})=\left\{\begin{array}{l}
1 \text { if } T 1<A B S[p(\mathrm{x}, \mathrm{y})-q(\mathrm{x}, \mathrm{y})] \\
0 \text { if } T 1<A B S[p(\mathrm{x}, \mathrm{y})-q(\mathrm{x}, \mathrm{y})]
\end{array}\right.
$$

Persamaan Pendeteksian Gerak Pada Metode Spatial Domain Dimana :

$\mathrm{f}=$ Array 2 dimensi yang digunakan untuk menyimpan hasil perhitungan.

$\mathrm{x}=$ Posisi pixcel terhadap sumbu $\mathrm{x}$.

$\mathrm{y}=$ Posisi pixcel terhadap sumbu $\mathrm{y}$.

$\mathrm{T} 1$ = Batas nilai untuk membatasi banyaknya perubahan nilai pixcel sebelum sebuah pixcel tersebut dinyatakan terhadap gerakan (Threshold). 


\section{Sound (Suara/bunyi)}

Bunyi atau suara adalah kompresi mekanikal atau gelombang longitudinal yang merambat melalui medium. Medium atau zat perantara ini dapat berupa zat cair, padat, gas. Jadi, gelombang bunyi dapat merambat misalnya di dalam air, batu bara, atau udara.

Kebanyakan suara adalah merupakan gabungan berbagai sinyal, tetapi suara murni secara teoritis dapat dijelaskan dengan kecepatan osilasi atau frekuensi yang diukur dalam Hertz $(\mathrm{Hz}) \quad$ dan amplitudo atau kenyaringan bunyi dengan pengukuran dalam desibel. Manusia mendengar bunyi saat gelombang bunyi, yaitu getaran di udara atau medium lain, sampai ke gendang telinga manusia. Batas frekuensi bunyi yang dapat didengar oleh telinga manusia kira-kira dari $20 \mathrm{~Hz}$ sampai $20 \mathrm{kHz}$ pada amplitudo umum dengan berbagai variasi dalam kurva responsnya. Suara di atas $20 \mathrm{kHz}$ disebut ultrasonik dan di bawah $20 \mathrm{~Hz}$ disebut infrasonik.

\section{Data}

Data merupakan fakta mengenai objek yang dinyatakan dengan nilai, baik berupa angka, huruf, simbol atau kombinasi lainnya. Data merupakan bentuk jamak dari datum, berasal dari bahasa Latin yang berarti "sesuatu yang diberikan". Dalam penggunaan sehari-hari data berarti suatu pernyataan yang diterima secara apa adanya.

\section{METODE}

Dalam melakukan penelitian, digunakan metode-metode berikut ini:

a. Field research (Penelitian lapangan)

Mekanisme yang dilakukan dalam melakukan penelitian lapangan adalah sebagai berikut:

i. Mengamati secara langsung kondisi kemanan disekitar lingkungan.

ii. Mengumpulkan data-data dari beberapa sumber yang bisa dipertanggungjawabkan keapsahannya baik dari sumber media elektronik maupun media cetak.

iii. Menanyakan kepada beberapa orang yang terlibat langsung dalam sistem tentang kendala yang dihadapi serta apa yang diharapkan dari sistem yang baru. Melakukan analisa dan perancangan sistem informasi berdasarkan data-data yang diperoleh.

b. Library research (Penelitian perpustakaan)

Membaca beberapa buku yang berhubungan dengan webcam dan buku yang berhubungan dengan konsep pemograman berorientasi objek.

c. Laboratory research (Penelitian laboratorium)

Penelitian dilakukan dengan memanfaatkan teknologi komputer dalam melakukan analisa dan desain sistem informasi. Adapun spesifikasi komputer yang digunakan adalah:

i. Hardware

- Webcam bawaan laptop

- ACER

- Processor Intel(R) Core(TM)2 Duo CPU

T5550@1.83GHz

- Harddisk 160 GB

- RAM 1024 MB

- Monitor 11 Inci

ii.Software

- Sistem operasi Windows 7

-Microsoft Visual Basic 6.0 sebagai bahasa pemograman client

- Microsoft office word 2007

- Visio 2003 sebagai pengolahan kata.

\section{HASIL}

\section{Analisis Sistem Yang Akan Dibangun}

Berdasarkan kebutuhan sistem dan hasil analisis sistem pengawasan di atas, maka sistem yang akan dibuat harus dapat memenuhi fungsifungsi sebagai berikut:

3.2.1 Sistem dapat memperlihatkan visualisasi keadaan dari area yang dipantau. 


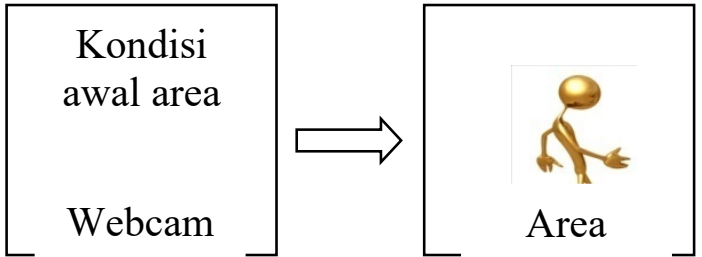

Gambar 3.1 visualisasi area yang diawasi oleh sistem security webcam.

Pada gambar diatas tampak kondisi awal area kosong kemudian sebuah area yang telah dipasangkan sistem keamanan security webcam tersebut tampak dimasuki oleh objek bergerak, maka secara otomatis webcam akan mengcapture objek tersebut dan menyimpan objek yang tertangkap dalam bentuk file gambar. Diharapkan dengan adanya sistem security webcam yang akan dibangun dapat meningkatkan keamanan sehingga mampu berperan dengan baik membantu penjaga keamanan untuk memantau suatu tempat atau ruangan. Dengan sistem security yang akan dibangun penjaga keamanan atau pihak yang akan menggunakan sistem ini akan dapat memantau ruang atau tempat dengan jelas dengan syarat tempat yang dipasangkan sistem keamanan harus memiliki cukup pencahayaan agar sistem dapat berkerja dan memperlihatkan visualisasi dari objek dengan jelas.

3.2.2 Dapat membedakan kondisi ruangan berdasarkan ada tidaknya pergerakan pada ruangan yang diamati.

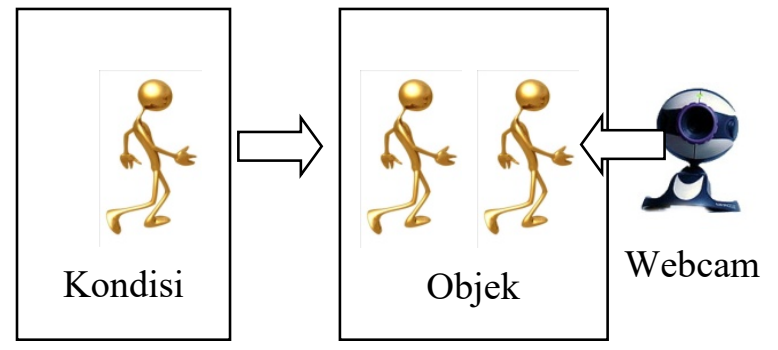

Gambar 3.2 visualisasi area sistem security webcam berdasarkan ada tidaknya pergerakan.

Sistem security wabcam yang akan dibangun ini berkerja dengan cara mendeteksi ada tidaknya memanfaatkan perbandingan antara picture 1 (satu) yang dilakukan pada saat pertama kali webcam difungsikan dan akan dibedakan dengan picture 2 (dua), tentunya dengan nilai sensitifitas yang telah ditentukan, jika antara picture 1 dan picture 2 yang ditangkap oleh webcam memiliki perbedaan atau objek bergerak makan dengan otomatis sistem akan mengcapture ndan menyimpan objek terdeteksi dalam bentuk file gambar.

3.2.3 Mampu menyimpan kejadian-kejadian yang dianggap penting.

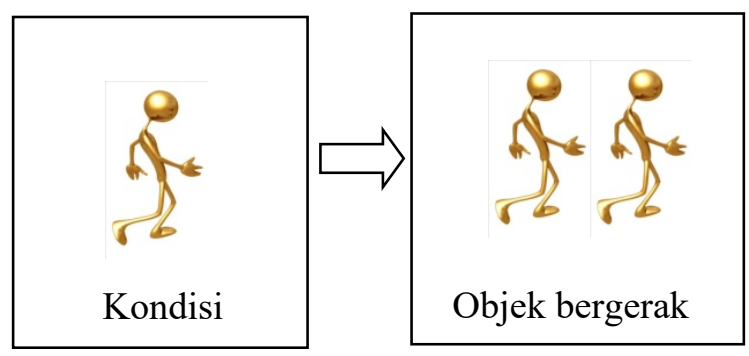

Gambar 3.3 visualisasi sistem security webcam yang mampu menyimpan objek terdeteksi.

Sistem security webcam yang akan dibangun, tidak hanya mampu mendeteksi adanya suatu pergerakan tetapi juga mampu menangkap dan menyimpan suatu pergerakan yang terdeteksi oleh webcam dalam bentuk gambar sehingga pengguna sistem ini akan dapat meriview kembali kejadian yang telah tertangkap oleh webcam. Cara kerjannya, sistem dirancang untuk membuat folder penyimpanannya sendiri yang akan terbentuk pada saat sistem dijalankan sehingga ketika webcam mendeteksi suatu objek bergerak dan melakukan proses mengcapture maka dengan otomatis objek yang terdeteksi akan tersimpan dalam bentuk gambar didalam folder yang telah ditentukan. 
Memberi alert berupa alarm pada saat terjadi pergerakan
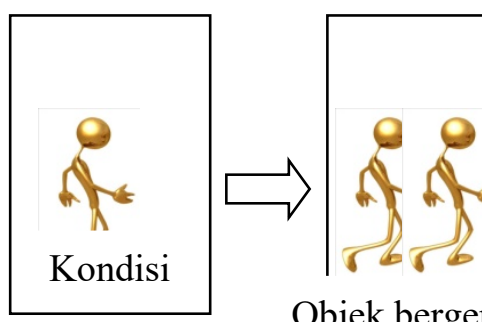

Objek bergerak

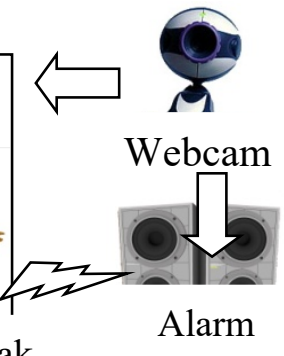

Gambar 3.4 visualisasi sistem security webcam yang mampu memberikan informasi berupa alert alarm.

Sistem security webcam yang akan dibangun tidak hanya dapat melakukan pendeteksian atau pun penyimpanan hasil dari objek yang terdeteksi melainkan juga dapat memberikan informasi kepada pengguna sistem jika terjadi sesuatu pergerakan yang tidak diinginkan, sehingga pihak pengguna yang menggunakan sistem ini akan dapat mengetahui kondisi ruangannya tanpa harus berada di depan layar monitor setiap saat karena sistem security yang akan dibangun dilengkapi dengan sitem alarm, yaitu informasi berupa sound alert (alarm) yang akan di lakukan oleh sistem jika terjadi suatu pergerakan yang tidak diinginkan apabila alarm berbunyi berarti telah terjadi suatu pergerakan yang tidak diinginkan diruang tempat sistem

dipasang, sehingga informasi lebih cepat diterima oleh pengguna sistem.

3.2.5. Menyeleksi area tertentu pada wilayah jangkauan kamera.

Sistem security webcam yang akan dibangun tentunya hanya akan melakukan eksekusi capture dengan batasan kemampuan kamera mengcapture sebuah objek yang bergerak dan apabila objek berada dari luar jangkauan daya tangkap webcam maka objek tidak akan dianggap ada dan sistem tidak akan melakukan eksekusi apapun. Karena itu penulis menganjurkan agar sistem ini hanya dipasang diruang dan tempat yang memiliki ruang lingkup yang terbatas agar kerja sistem dapat optimal.

\section{Arsitektur Sistem Deteksi Gerak}

Sistem yang akan dibangun terdiri dari webcam bawaan pada laptop untuk pengambilan gambar, laptop sebagai pengolah data serta speaker untuk alarm keamanan. Arsitektur sistem secara umum dapat dilihat pada gambar 3.5. berikut:

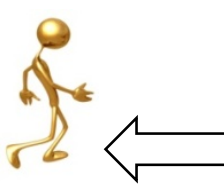

Objek

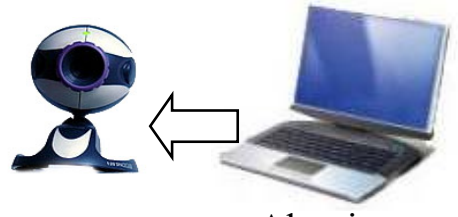

Capture
Algoritma pendeteksi gerak
Gambar 3.5 Blok diagram sistem deteksi gerak

Sistem security webcam yang akan dibangun meliputi webcam yang terdapat pada laptop dan speaker sebagai media output sound alert jika webcam mengcapture suatu objek. Citra yang dipilih adalah citra 24-bit sehingga dikenali sebagai citra RGB. Citra RGB adalah citra yang tersusun dari kombinasi tiga warna dasar (merah, hijau, biru). Ketiga warna tersebut dapat menghasilkan kombinasi warna yang sangat banyak, sesuai dengan kadar dari setiap warna tersebut. Hal ini membuat proses pengolahan citra menjadi kompleks dan panjang. Program yang dibuat mendeteksi perubahan citra dan proses pendeteksian gerak menggunakan proses deteksi tepi, dimana sistem melakukan perbandingan antara capture pertama dan capture ke dua. Dan sistem akan memberikan informasi secara otomatis berupa alert alarm jika adanya suatu pergerakan.

\section{Desain input}

Desain Program merupakan desain aplikasi yang digunakan sebagai Grafik User 
Interface (GUI) sebagai bentuk tampilan dari program security webcam dengan memanfaatkan Visual Basic (6.0).

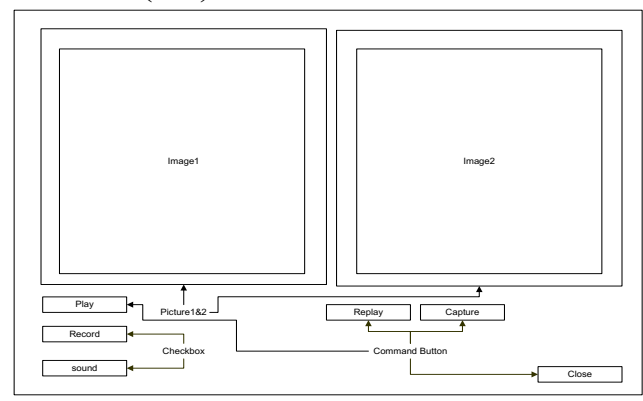

Gambar 3.6. Desain input sistem security wabcam

3.4.1 Perancangan dan pembuatan Graphical User Interface (GUI)

Tujuan dari perancangan GUI (Graphical User Interface) adalah untuk mendapatkan hasil kinerja maksimal dari interaksi manusia dan komputer. Tampilan GUI yang baik adalah tampilan yang memberikan kemudahan dan efisiensi bagi pengguna. GUI yang dibuat harus mendukung control-control sebagai berikut:

1. Play : untuk memulai sistem.

2. Stop : untuk menghentikan sistem.

3. Setting : untuk mengatur sistem.

a. Record untuk mengaktifkan Video

b. Sound untuk mengaktifkan alarm

4. Exit : untuk keluar dari sistem.

\section{Desain output}

Desain output merupakan hasil keluaran dari masukan dan proses atas data yang telah diolah oleh sistem security webcam.

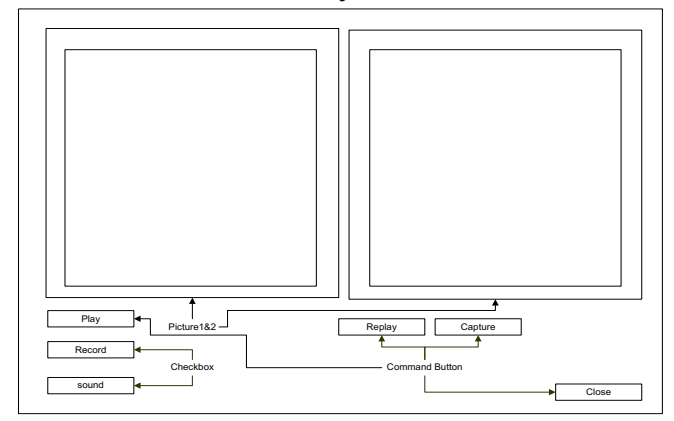

Gambar 3.7. Desain output sistem security

DOI : https://doi.org/10.36341/rabit.v1i2.23
Pada gambar 3.7 tampak webcam menangkap sebuah objek yang pada awalnya posisi objek berada di sebelah kiri jika dilihat dari sisi monitor kemudian objek bergerak kearah kanan maka secara otomatis sistem akan mengcapture objek dan menyimpannya dalam bentuk file gambar serta memberikan informasi berupa alert alarm kepada pengguna sistem.

\section{Implementasi Aplikasi Security Webcam}

Pada bagian ini dijelaskan mengenai tampilan program dari aplikasi security webcam serta penjelasan fungsi dari masing-masing fiture-fiture yang terdapat diaplikasi. Berikut tampilan dari aplikasi sistem security webcam.

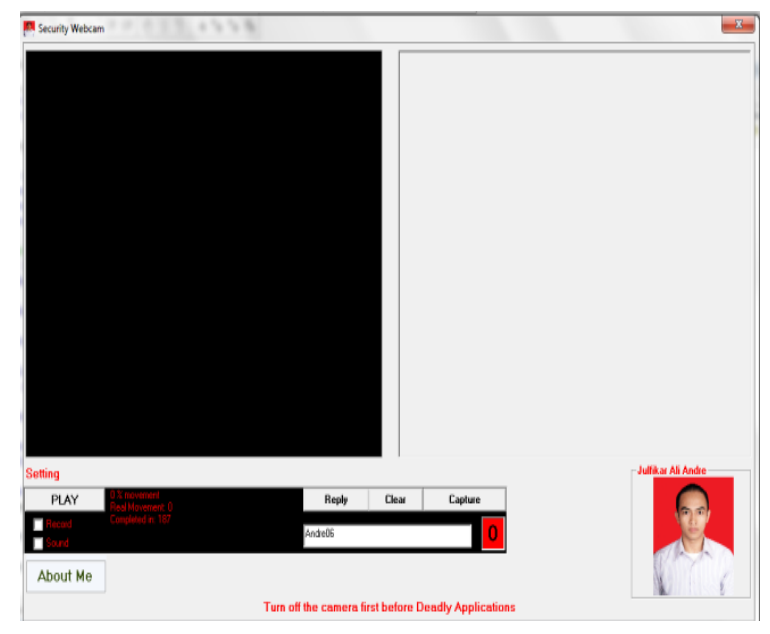

Gambar 4.11. Tampilan aplikasi sistem security webcam

Tombol play pada jendela berfungsi untuk mengakses kamera webcam yang dituju, dan akan menampilkan citra yang terekam kamera pada tampilan jendela program utama. Untuk mengaktifkan alarm pendeteksi gerak, maka perlu dilakukan penekanan/atau pemilihan menu sound yang terdapat pada tampilan program. Setelah tombol tersebut ditekan maka program akan melakukan kalkulasi pada setiap frame yang terekam. Bila dideteksi adanya suatu gerakan maka program akan membunyikan alarm dan mengcapture objek yang terdeteksi, untuk 
menghentikan alarm tersebut cukup dengan menghilangkan tanda check list pada tampilan program. Sedangkan menu check list record pada program berfungsi untuk mendeteksi objek bergerak serta mngcapture objek yang terdeteksi dan hasil dari gambar yang terdeteksi oleh webcam dapat diputar kembali layaknya sebuah video rekaman. Kemudian tombol capture berfungsi untuk mengcapture image secara manual dan tombol clear berfungsi untuk menghapus image yang telah dicapture secara manual, berikut tampilan program saat dijalankan.

1. Tampilan saat memilih about me pada aplikasi.

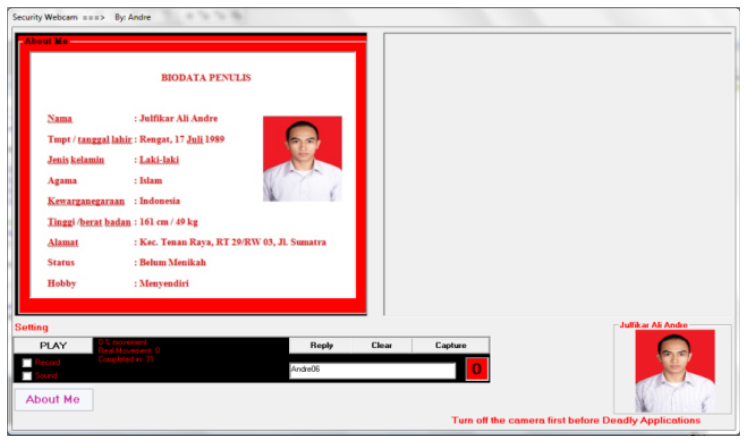

Gambar 4.12. Tampilan aplikasi sistem security webcam untuk about me

2. Tampilan saat pertama webcam dinyalakan.

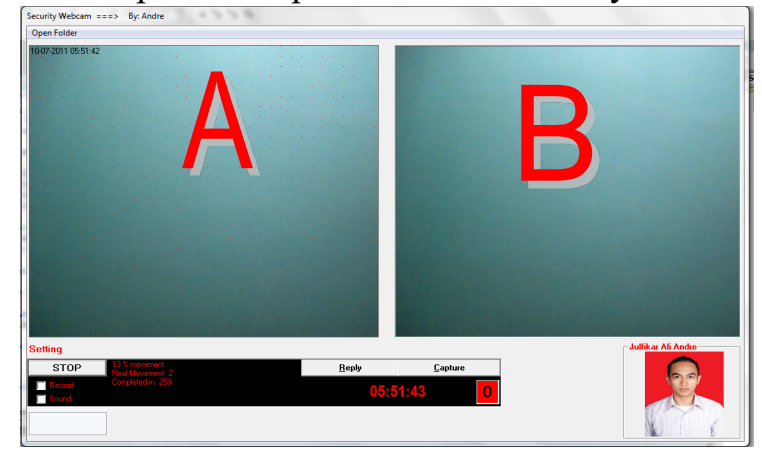

Gambar 4.13. Tampilan aplikasi sistem security firts run application

Saat pertama kali webcam dinyalakan tampak pada layar A dan B tidak adanya perubahan apapun sehingga sistem tidak akan memberikan informasi apapun.

3. Tampilan saat memilih menu check list sound alarm pada aplikasi.

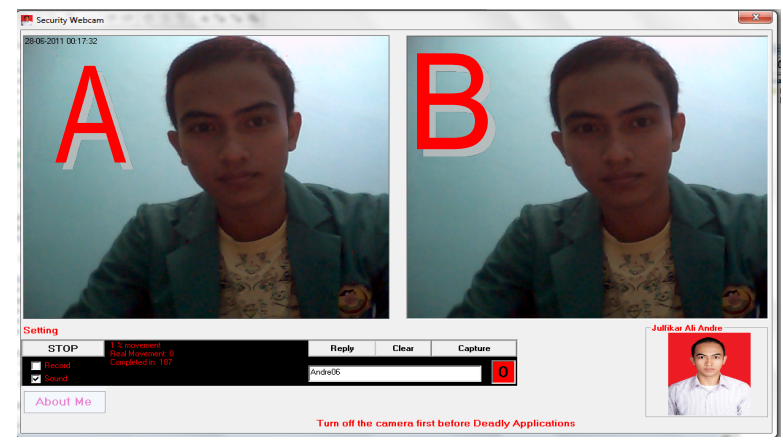

Gambar 4.14. Tampilan aplikasi sistem security webcam untuk menu check list Sound.

Gambar A menunjukkan kondisi awal objek terdeteksi dan objek tersebut melakukan sedikit pergerakan yang kemudian ditunjukan pada gambar B. Jika pengguna atau user memilih check list sound maka pada saat webcam menangkap suatu objek maka secara otomatis sistem akan membaca atau mengeksekusi coding sound yang telah dibuat, sehingga alarm berbunyi memberikan informasi kepada pengguna atau user bahawa sistem menangkap suatu objek bergerak. Alarm akan berhenti berbunyi apa bila benda atau objek tidak melakukan gerakan apapun atau tidak terdeteksi oleh webcam lagi.

4. Tampilan saat memilih menu check list record

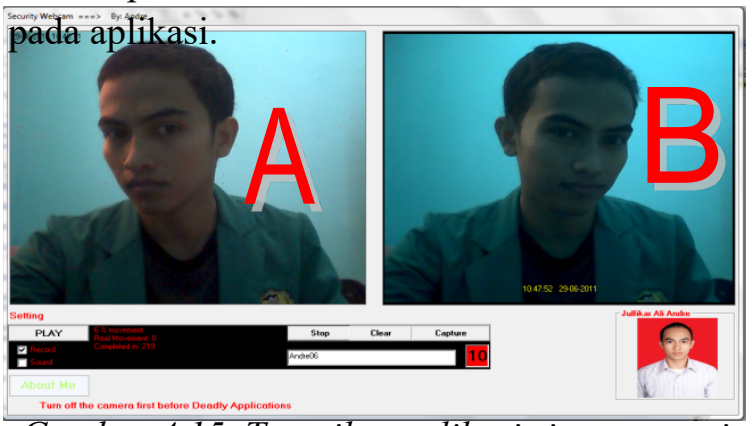

Gambar 4.15. Tampilan aplikasi sistem security webcam untuk menu check list record 
Gambar A menunjukkan kondisi awal objek terdeteksi dan objek tersebut melakukan pergerakan yang kemudian ditunjukan pada gambar B jika pengguna atau user memilih check list record maka pada saat webcam menangkap suatu objek maka secara otomatis sistem akan membaca atau mengeksekusi coding untuk mengcapture gambar yang telah dibuat, hasil dari objek yang tercapture akan tersimpan di sebuah folder, diamana folder tersebut dapat dipanggil kembali jika suatu waktu dibutuhkan lagi. Dimana hasil capture dapat diputar lagi dengan menekan tombol replay yang terdapat pada aplikasi.

\section{KESIMPULAN}

Dari hasil pengujian dan analisis sistem security webcam yang dibangun dengan menggunakan Visual Basic (6.0) maka dapat disimpulkan hal-hal sebagai berikut:

1. Penentuan posisi webcam dan pencahayaan memiliki pengaruh besar dalam pengenalan objek, untuk itu dibutuhkan pengesetan webcam dan pencahayaan yang cukup.

2. Tingkat kemampuan program pendeteksi gerakan akan cenderung menurun, dikarenakan webcam tidak dapat merekam gambar secara sempurna. Sensitivitas webcam untuk mendeteksi suatu objek tergantung pada cahaya objek tersebut. Apabila pada cahaya semakin terang, tingkat sensitivitas webcam semakin bagus. Namun apabila pada cahaya semakin gelap, tingkat sensitivitas webcam semakin menurun.

3. Kualitas webcam juga berpengaruh untuk mengolah citra yang dihasilkan dari kecepatan pergerakan objek tersebut. Apabila benda bergerak terlalu cepat dengan kualitas webcam yang bagus, maka akan memperoleh hasil pengolahan citra yang maksimal. berpengaruh adanya pencahayaan di ruangan tersebut. Apabila ruangan tersebut terlalu gelap alarm tidak akan berbunyi. Pengaruh alarm berbunyi bisa saja bukan dari pergerakan yang disengaja, misalnya objek diam yang terkena angin.

\section{DAFTAR PUSTAKA}

[1]. Darma Putra, 2006. Pengolahan Citra Digital. Penerbit Andi,Yogyakarta.

[2]. Doug Rosenberg, Matt Stephens, Use case driven object modeling with UML: theory and practice.

[3]. Ferry Gunawan, 2005. Sistem Pendeteksi ruangan dgn Sinar Laser. Penerbit PT Elex Media Komputindo, Jakarta.

[4]. Jogiyanto, HM. 2005. Analisis Dan Desain Sistem Informasi: Pendekatan Terstruktur Teori dan Praktek Aplikasi. Penerbit Andi, Yogyakarta.

4. Alarm akan berbunyi apabila adanya pergerakan suatu objek. Akan tetapi juga 